\title{
Humanitarianism, civil society, and the Rohingya refugee crisis in Bangladesh
}

\author{
David Lewis
}

Accepted by Third World Quarterly forthcoming 2019

\section{Introduction}

On landing at the airport at Cox's Bazar, Bangladesh in early March 2018, I made my way down the steps from the plane and noticed a small group of well-dressed men standing not far away. They were unfurling a large banner that said 'Humanitarian Relief to Rohinga (sic) Refugees', sponsored by Charity for Life, Sydney, supported by the Tangail and Cox's Bazar Rotary Club, and implemented by Mukhti Cox's Bazar, a small local non-governmental organisation (NGO). They had driven their minivan onto the tarmac to meet two colleagues off the plane from a counterpart Rotary Club association in Sydney and were now posing for a celebratory picture. There followed a series of photographs in front of the banner, which I was also invited to join, perhaps intended as a way of adding to the international flavour of the proceedings, but I declined as I felt I might be getting in their way. But having been asked to become a part of what looked like some kind of performance, and viewed as having something I could bring to what was happening, I began to reflect what exactly was being performed and why. It appeared to me that I was witnessing a distinctively inclusive and spontaneous form of voluntary action, that was easily stretched across scales and appeared ready to accommodate a wide range of identities.

In 2017 almost a million mainly Muslim Rohingya refugees fled sustained statesponsored violence in Burma to cross into the Cox's Bazar area of south-eastern Bangladesh. Makeshift camps were soon set up and the crisis quickly began to receive international media attention. ${ }^{1}$ On the ground, there were reports of person to person support through which local people began responding, including spontaneous forms of informal helping, volunteering, distribution of packages of clothing and food, and collecting and giving money. While such early responses began as essentially local forms of action, they were soon joined by other help givers working at national and transnational scales of operation and over the space of a few months these evolved into a large-scale humanitarian response.

This paper offers a reflection on what happened during those early stages of the response, and considers the ways in which humanitarian actions were performed by various actors as the crisis unfolded. It begins with an account of this early response period in the weeks that followed the increased numbers of Rohingya refugees arriving from Myanmar during late August 2017. Drawing on recent literature on the local and international dimensions of humanitarianism, this narrative is then unpacked in order to explore aspects of citizen aid including the changing nature of Bangladesh's civil society, forms of religious solidarity and charity, and the importance of understanding these responses historically. The discussion draws on local and international press coverage, semi-structured interviews retrospectively conducted with local journalists and humanitarian personnel in March 2018, both in Dhaka and in Cox's Bazar, ${ }^{2}$ and on the author's longstanding engagement with issues of state and civil society in Bangladesh. 
Recognition that humanitarian responses takes different forms and operates at different scales is important both in understanding local events, and in challenging dominant media and agency representations which tend to give certain forms of response higher visibility than others. Giving attention to forms of small-scale humanitarianism unsettles our more familiar and established narratives of international aid and development to reveal more of the depth, diversity and complexity of humanitarian action. As Redfield and Bornstein have suggested, the concept of humanitarianism is multifaceted: 'a structure of feeling, a cluster of moral principles, a basis for ethical claims and political strategies, and a call for action'. ${ }^{3}$ Its diverse manifestations are sometimes expressed as the contrast between large-scale humanitarian action carried out by high profile non-governmental organisations with vast budgets and the less visible acts of helping or giving that are carried out by small groups or individuals seeking to express social concerns and identities. Erica Bornstein also reminds us that everyday forms of person to person helping are not only diverse but may also be 'spontaneous, informal, unmediated, and habitual'. 4

This diversity is partly captured by the general term 'everyday humanitarianism', which has come to be used in various ways in the literature. Some have used it simply to recognise the diversity of humanitarian action within 'myriad forms and practices' from individual to organisational, corporate and state levels. ${ }^{5}$ Others have deployed it to contrast 'insider' and 'outsider' forms of helping, or to contrast high profile formal humanitarian action with less visible, more spontaneous, smaller scale grassroots responses. Moving beyond these different ideas, and the limitations of formal/informal dualism, at a general level the term helps expand our understanding of the 'aims, technologies, and participants' of humanitarian action, and serves to highlight the sometimes overlooked experiences of local volunteers as they attempt to navigate different scales of helping and negotiate its associated tensions. ${ }^{6}$

Within less visible worlds of informal voluntary action other terms such as 'citizen aid', 'grassroots humanitarianism', and 'person to person helping' are also used to convey the diversity of such activities. These reinforce the idea that such action needs to be understood on its own terms rather than according to outside categories, and the importance of contextual, structural and historical factors. Such terms are, as the editors of this issue have suggested, somewhat unstable categories that nevertheless offer a useful handle on the diverse forms of citizen helping and may illuminate the wide range of activities and motivations involved in humanitarian action across different settings and scales. As Hilhorst and Jansen have argued, humanitarian space can be understood as an 'arena' in which different actors seek to shape the nature and form of humanitarian action in terms of its 'everyday realities' through a range of different and frequently competing motivations. ${ }^{7}$ I argue here that concepts of local helping or everyday humanitarianism also need to be historicised in the Bangladesh case by contextualising them within peoples' own experiences and memories of having themselves once been refugees.

The lens of performance provides a further way of analysing humanitarian response in terms of diversity, process and change over time. ${ }^{8}$ For example, James Thompson's analysis of case studies of Kosovo, Darfur and the Asian tsunami highlights how humanitarian performances may be understood as containing certain common characteristics - such as the communication of a narrative of suffering to different 
audiences, the spotlighting of certain key events within these narratives, and the purposeful contrasting of heroes and victims. ${ }^{9}$ These tropes are also ones that feature in the Rohingya case.

The focus in this article is on the early stages of the crisis during the second half of 2017 and on the forms of spontaneous person to person helping with which the Rohingya refugees were greeted by many Bangladeshis. These small-scale acts tend to receive less attention than the work of formal agencies such as NGOs and intergovernmental agencies, but they lie at the heart of voluntary action in most societies, and are far from new. At the same time, local citizen responses of this kind cannot be fully understood without reference to the Bangladesh state. The state played an important role not only in coordinating responses to the refugee crisis, but also in representing it, in particular through its effort to build representations of the crisis into wider political narratives of national generosity and religious piety. These narratives draw on local and national identities formed within Bangladesh's own history of struggle and crisis, and lend support to the ruling Awami League's (AL) ongoing efforts to demonstrate to its domestic and international audiences that it has earned the right to be seen as the 'natural' party of government.

\section{The 2017 Rohingya crisis and the responses}

Although the space is not available here to do full justice to the origins of the crisis, some brief background information is required to contextualise the case presented here. The Rohingya are a group of people, predominantly Muslim, who live mainly in Western Burma. Their language, ethnicity and religious identity is regarded by the Myanmar authorities as separate from mainstream Burmese cultural identity. As a result, they have experienced discrimination, persecution and religious oppression for many decades. ${ }^{10}$ The historical roots of the problem are complex, going back as far as when the British seized parts of Burma in 1824, from which time the territory of Burma was incorporated as part of British India, and beyond. Today's international border between Bangladesh and Myanmar was simply a boundary between districts during the colonial period across which the British authorities regularly moved populations in line with labour requirements. ${ }^{11}$ Burma's border with India was porous and the boundaries of the coastal region of Arakan (now part of today's Rakhine State) - the area where most Rohingya live - were never formally demarcated when Burma was separated from British India in 1937. After Burmese independence was obtained in 1948 the large Muslim minority population living in Arakan was excluded from citizenship. A key element of the Myanmar state's continuing refusal to grant citizenship is the assertion that the Rohingya did not form part of the state's pre-1824 population and that they therefore do not therefore qualify as a recognised minority group. ${ }^{12}$

Conflict and instability have led to many waves of Rohingya refugees in recent times seeking refuge in Bangladesh, including in 1978, the early 1990s, 2007 and 2012. Such movements of people have been the result of Burmese government policies and longstanding tensions between Muslims and the majority Buddhist population in Rakhine state, where the Rohingya remain a significant minority, continue to be denied citizenship and are officially viewed as illegal migrants from Bangladesh. ${ }^{13}$ In 2012, for example, more than 200 people were killed and 140,000 displaced when Buddhist extremists attacked Rohingya homes and businesses in Rakhine State in 
retaliation that followed a reported assault on a local woman. ${ }^{14}$ The crisis that began on August 252017 was precipitated with an attack by Rohingya militants on police posts. What followed was a strategy of organised mass violence perpetrated by the Myanmar army and its local collaborators, including the murder of more than 6,700 Rohingya in the month that followed, the systematic use of rape as a weapon, and the destruction of at least 288 Rohingya villages. ${ }^{15} 16$ This violence prompted the large scale exodus of people across the border to Bangladesh.

Through highly visible acts of individual and national generosity, first the Bangladeshi people, and then later the government, began to express their solidarity with the Rohingya refugees and initiated various forms of helping. Support started to be offered almost as soon as refugees began arriving in late August. On the Bangladesh side of the border people were immediately moved by the scale of the movement of people to give money, food, and shelter in a spontaneous outpouring of person to person helping and private giving. ${ }^{17}$ Some local businesses started organising meal deliveries, and provided clothes and housing materials to traumatised people struggling to cope. Individuals and groups from around the country also soon began arriving in the small town of Cox's Bazar, some with hired trucks from which they started an ad hoc distribution of food and other relief goods.

It was several weeks before the government began to take control of the situation. It was reported to me by one local aid official who was from a military family that the emotional responses of members of the local coast and border guards who were on duty at that time was an important factor in drawing attention to the severity of crisis and driving the response. Some of these guards were so distressed by the condition of the Rohingya people who were arriving, and by their stories of organised violence, killings and rape, that they began sharing their experiences with other colleagues and family the armed forces. Senior military figures reportedly told Prime Minister Sheikh Hasina that they needed the government to act in order to avoid a loss of morale and even discipline among their personnel. This began the process of establishing army control in which land was commandeered and cleared, camp facilities established, and governance structures put in place.

Prime Minister Hasina responded by taking on a personal leadership role, although it is not known how far her stance was shared among all members of the cabinet. In a widely quoted declaration, she announced 'If needed, we will eat a full meal once a day and share the rest with them. ${ }^{, 18}$ The government agreed to provide food and shelter to the Rohingya, but also made it clear that the new settlements would be only temporary until the refugees - or forcibly displaced citizens of Myanmar, as they were being termed in 2018 - were in a position to return to their homes. Negotiations with the Myanmar government have been ongoing regarding the return of the refugees, but at the time of writing (mid 2019) there are few people who believe that this will happen given prevailing conditions in Rakhine state where Rohingya villages remain destroyed. ${ }^{19}$

During the weeks that immediately followed the arrival of the refugees, there were charitable responses from a variety of individuals and groups. These were largely spontaneous and loosely organised, and reports of the generosity of local residents briefly became a global news story. Many of Bangladesh's citizens were immediately volunteering and offering help to the Rohingya refugees, including people living in 
the border region and those coming from other parts of the country. An element of this story was the fact that there was a widespread international perception of Bangladesh as a country more used to receiving aid than giving $i^{20}$, crudely stereotyped as one of the world's poorest and heavily overpopulated nations.

On September 14th 2017, Al Jazeera's Katie Arnold reported: 'Moved by their suffering, citizens of Bangladesh have rallied together to deliver much-needed assistance to the new arrivals. Most distribute their goods from large trucks that now clog the rural road between Cox's Bazar and Teknaf'. ${ }^{21}$ The article highlighted two contrasting modes of spontaneous person to person helping: the sharing of resources and space by those with very little, and the charitable distribution of largesse by the better-off, and these can be briefly contrasted. There are two briefly sketched portraits of individual 'helpers': one a self-described 'poor farmer' named Abu Hayed from a local village near Teknaf, who was providing shelter on his property to eight Rohingya refugee families; and the other a well-off Dhaka based middle class 'digital entrepreneur' named Mehedi Chowdhury, who was reported as having decided to give all his savings to support the refugees. Mr Hayed had given incoming families the use of an 'old cowshed' as a temporary shelter that offered space for the children to play, access to drinking water and was providing them with regular food. He explained his actions in terms of simple human support as a citizen expecting his government to take action:

'I gave them shelter because I am a human being - it is raining outside, they have nowhere to sleep, they are totally helpless. But I am a poor farmer, with a large family. I am trying to transfer them to a camp, but I am not getting any support,' he says, passing a glass of water to one of his tenants.

In contrast, $\mathrm{Mr}$ Chowdhury is presented in the report as a successful urban citizen, very much a part of Bangladesh's new dynamic high-growth economy and its growing middle class. For him, the Rohingya crisis provides pause for thought and reflection, and appears to have led him to a moment of questioning and postponement of the materialist dream of this new Bangladesh to make a sacrifice. Rather than buying a new car as he was planning to do, the article explains, Chowdhury had decided instead to use the money to help the Rohingya refugees. He donated around US $\$ 9000$ in order to buy tents and food parcels and became directly involved in distributing them, hiring trucks and handing out relief goods himself to crowds of refugees. He explains his actions partly in humanist terms, but reports that he is also influenced by a sense of religious solidarity:

'They are Muslim, and they are being persecuted because they are Muslim, that strikes a chord with me ... and there is only so many times you can watch videos of someone being beaten or raped on Facebook - I had to come here and help,' says the 29-year-old.

This citizen helping effort is portrayed as hugely appreciated by the Rohingya refugees at the roadside, one of whom is quoted as saying

If it wasn't for the Bangladeshis I don't know how we would survive. There is no space in the camps, and no international organisations have offered us support. 
The first few weeks of the crisis had seen largely uncoordinated 'person to person' efforts to meet some of the Rohingya's more immediate needs, but people soon started organising in groups and associations. For example, the national newspaper Prothom Alo as part of its community outreach work sponsors a network of community groups known as 'bondhu sabha' or friends clubs. These groups began arranging collections of winter clothes, sanitary towels, biscuits, and lunghis. Other small community level associations like Shopna Shiri (Ladder of Dreams) and Kelagor (Playroom) collected money and distributed relief materials. A number of small local NGOs who were already working in the area such as Coast Trust soon began to undertake fundraising and the distribution of relief goods. At the same time, voluntary action by students from the Cox's Bazar Government College, who became involved in collecting food and relief goods for the refugees, provided another example of the diverse, multiple actors operating across private and public domains. Finally, private sector businesses also became involved, such as the Seagull Hotel where staff prepared and distributed hundreds of free meals each day for refugees, an example of charitable action from the for-profit commercial sector.

Yet there was also a growing sense of unease in the Al Jazeera article, as the limitations of such small scale action were becoming apparent. First, certain limits of person to person helping became apparent, with the article noting that children could be seen to be fighting over scraps of food in the street. There is also a description of Mr Chowdhury's efforts to throw food parcels from his vehicle outside one of the camps one evening that rapidly escalates out of control, creating a difficult situation in which his truck became surrounded by people engaged in a 'tense and sometimes violent struggle'. When the supplies ran out, people climbed onto the truck to help themselves to whatever was left, leading Chowdhury reportedly surprised that people could fight over food, and reflecting on his own fear at the sight of such desperation: 'I thought we were going to die'. Brought into closer contact with a section of his own society in ways that he had not previously experienced, he seemed to have become discomforted. Although he is not explicitly critical of the mainstream relief agencies, Mr Chowdhury's prioritisation of the need for immediate and personalised action is reminiscent of Hilhorst and Jansen's (2010) category of the 'non-governmental individual' as a form of humanitarian actor whose numbers are growing and whose amateurism and informal helping can sometimes be the focus of criticism by aid professionals.

At the same time as these local efforts were taking place, a more formal response by the Bangladesh government and the international community soon got underway. For example, the local government's District Commissioner's Office started taking in donations and distributing resources. As Richey and Chouliaraki suggest, tendencies towards formalization may arise within local humanitarian efforts and operations become routinized and practices rationalized over time. ${ }^{22}$ Once the initial month of mainly informal helping was over, the area around the town of Cox's Bazar quickly became the location for one of the world's largest formal humanitarian response efforts.

This formal response brought together a range of international agencies - with a few local ones - that soon became coordinated by the Government of Bangladesh. The government had already in 2013 put in place a National Strategy on Myanmar 
Refugees and Undocumented Myanmar Nationals. Under this strategy the government moved during late 2017 to establish a National Task Force, chaired by the Ministry of Foreign Affairs, comprised of 22 Ministries and other bodies. This offered strategic oversight of the overall response to the needs of the undocumented Rohingya. The humanitarian agencies were coordinated by the Strategic Executive Group (SEG) located in Dhaka, co-chaired by the Resident Coordinator, the international Organisation for Migration (IOM), and the office of the United Nations High Commissioner for Refugees (UNHCR). The SEG helped the agencies coordinate with national level government engagement and liaise with the National Task Force.

In broader historical perspective these administrative arrangements can be seen to rested on two longer term foundations: the history of efforts to manage earlier waves of Myanmar refugee arrivals to the area, and the government's long experience of responding to Bangladesh's own regular humanitarian emergencies created by its vulnerability to tropical cyclones and large scale flooding. ${ }^{23}$ For example, at District level, an existing Refugee Relief and Repatriation Commissioner (RRRC), under the Ministry of Disaster Management and Relief, which was established during the early 1990 s to look after the 34,000 or so refugees who arrived at that time, had its mandate extended in 2017 to cover operational coordination for the newly increased refugee population. An administrative structure quickly took shape in which the District Commissioner (DC) took responsibility for coordinating operations among the Bangladeshi host communities affected by the crisis, and a Senior Coordinator (SC) was put in place to lead the response on behalf of the humanitarian agencies, liaising with the DC (and with other officials at the sub-District level) and with the RRRC. The SC chaired the Heads of Sub-Office (HoSO) Group that brought together the heads of all the UN Agencies and the representatives of the international NGO and national NGO communities, as well as two representatives from the donor community based in Cox's Bazar.

Alongside these government arrangements many international NGOs also formed a key part of the response, working in a variety of roles. For example, Save the Children Fund (SCF) had worked in the area since 1970, focusing on the needs and rights of children, particularly those unaccompanied and vulnerable to exploitation and trafficking. By early 2018 it had expanded its presence in Cox's Bazar to 1,400 staff members and with a mix of local and international volunteers distributed tents, cooking and hygiene kits to refugees. ${ }^{24}$ Oxfam GB, also present in the area since the 1970s, was active in monitoring responses to ensure that the water, sanitation, and hygiene facilities being constructed met international humanitarian standards, and provided clean drinking water, portable toilets and sanitation facilities, and plastic sheets for shelter. Médecins Sans Frontières, active since 1985, had deployed 2,000 staff members providing treatment for dehydration, diarrheal diseases, and violencerelated injuries. Other international NGOs have more recent histories in the area. For example, Action Against Hunger, with a local presence since 2007, deployed around 700 staff members and 1,000 volunteers in the delivery of hot meals and water, as well as providing treatment for malnourished children and mental health counselling for the large numbers of people affected stress and trauma.

Despite the many international NGOs, the largest non-state presence on the ground in 2018 was a Bangladeshi development organisation established in 1972 known as BRAC. ${ }^{25}$ One of Bangladesh's leading civil society organisations, BRAC is active 
throughout the country with its wide range of development programmes. ${ }^{26}$ Expanding its relatively small presence in Cox's Bazar where it had been engaged in community level work it moved quickly to deploy 1,300 staff, and a further 800 Rohingya refugees were trained as volunteers to undertake health and education activities and measures for the protection of women and girls. ${ }^{27}$

Also active for many years in the overall response efforts are various religious (or 'faith based') international NGOs such as Islamic Relief and Muslim Aid. The former has worked with the Rohingya since 2008, when it constructed settlements for 10,000 unregistered Rohingya refugees in the Teknaf area. The organisation provided food and shelter to the new arrivals, but along with Muslim Aid was reported as experiencing tension with the authorities after allegations were made that along with some other groups it had distributed materials sympathetic to the Jama'at-i-Islami (JI) political party, which is banned in Bangladesh. This controversy led in October 2017 to restrictions being placed on this organisation's activities, and those of some other religious groups', in the camps. ${ }^{28}$ Alongside such organisations there were also less formalised types of transnational religious charity, including madrasa support, income generation skills training projects, and mosque based initiatives. Also present were diaspora organizations (such as the one encountered by the author in the introduction) operating, through which earlier waves of migrants and refugees may undertake support and advocacy activities with people who are displaced elsewhere in the world. ${ }^{29}$

Both individualised citizen response and more formal interventions have continued to operate side by side, though by the end of 2017 the former had become overshadowed by the latter in terms of scale and resources. As the government, the army and the agencies took control of the situation, the humanitarian arena was transformed into a more tightly governed and ordered refugee space (see Hilhorst and Jansen 2010). Person to person forms of humanitarian action can be understood as a response to the absence or breakdown of order, and as helping to build a transition towards more stable arrangements. Tensions emerged not only within the different levels of the formal response (for example between international and local NGOs, religious and secular agendas, and government and non-state actors) but also with local responses. Informal logics of citizen helping were reported as occasionally coming into conflict with the differently organised world of professional aid and agencies. For example, Chris Lom from the IOM was quoted as being critical of the informal resource distribution methods used in some small scale citizen efforts and illustrated by the $\mathrm{Mr}$ Chowdhury example above: "The only way to do this is to walk through every camp, identify those in need, give them a token and invite them to an orderly distribution centre. $^{, 30}$

\section{Civil society, continuity and change}

Bangladesh's civil society has received considerable attention as one of the contributing factors to the country's achievements in reducing poverty and overcoming the imposition of military government during the 1970s and the 1980s. The role of the student and language movements in the country's struggle for independence has been well documented, as has the growth of the indigenous or national NGO sector that subsequently played a key role in the country's progress with reducing social disadvantage, such as maternal mortality, and improving access 
to education. By the 1990s it had become common for Bangladesh to be characterised as a vibrant civil society, based on these longstanding traditions of citizen action, resistance and social movements, and on its high profile set of large-scale development NGOs. These NGOs were not only providing education, health and credit services to poorer citizens but were also now engaging in forms of 'small p' politics through local community organising and national level advocacy. ${ }^{31}$ Analyses have tended to focus on the developmental and political dimensions of these non-state actors, but less attention has been paid to historical, cultural and performative aspects of the civil society sector, or to its local smaller scale manifestations. The case of the 2017 Rohingya crisis provides a new perspective on these themes and offers insights into the ways that civil society is changing.

Bangladesh has successfully pursued an export oriented growth strategy the past two decades. This has aided the expansion of a new middle class, part of which has become associated with a changing religious outlook. ${ }^{32}$ The forms of citizen helping that became visible during the Rohingya crisis can be understood as part of middle class distrust and even rejection of the formalised NGO sector, viewed by some people as over-professionalised and too corporate, or as tainted by political interest and corruption. NGOs have come to be seen as part of an increasingly partisan and compromised civil society. While NGOs were once associated with poverty reduction, social innovation and radical rights-based action, today's version of civil society is less diverse and homogenised by the dominant emphasis on market-based approaches and service delivery. It is more constrained - in the sense of having been captured by party interests and patronage networks - leaving its organisations unable to play progressive roles in strengthening democratic citizen participation. ${ }^{33}$

For a substantial element of this new middle class, the renewal of Islamic identities is providing alternative ways of imagining and performing charity and philanthropy and is contributing the shaping of a different kind of civil society. ${ }^{34}$ As Samia Huq points out, while Bangladesh's founder Sheikh Mujib's earlier nation building narrative had initially emphasised secularism, this initial period is increasingly remembered as one 'where the issue of religion, especially that of the majority population, was inadequately factored into discussions of national identity'. ${ }^{35}$ The 2017 refugee crisis and local responses offer one entry point for gaining insights into the ways that some social groups, and the government itself, are now seeking opportunities for a resettling of this discussion. Within this changing vision, religiously informed public action serves as a counterweight to the perceived corruption of secular public officials, political party activists and civil society leaders, while more personalised forms of direct helping offer an alternative to the image of the domestic and international poverty industry with its cosmopolitan professionals, air conditioned offices, donor money and expensive 'logo-ed' sports utility vehicles.

The religious and personal dimensions of everyday forms of humanitarian action may be understood as part of efforts to modify or even purify what some citizens have come to regard as a tainted secular vision of civil society, and as a microcosm of the wider secular-religious shifts taking place in Bangladeshi society. The government seeks to maintain its legitimacy and its support base by tracking and reflecting these changing religious sensibilities, both by building coalitions with religious groups and by ensuring that it signals public recognition of religious sentiments. For example, in 2018 the government moved to make the Qawmi Madrasa hadith qualification 
equivalent to a master's degree in Islamic Studies and Arabic. This strategy is also reflected in the government's handling of its humanitarian response to the Rohingya crisis. It is not surprising then that religion has a powerful role in today's landscape of compassion and voluntary action. The fact that the Rohingya are predominantly Muslim and have been so visibly the victims of religious persecution is important for understanding both local and international responses to the crisis. This resonates with Erica Bornstein's concept of 'lifestyle evangelism' in which faith can be understood as a key motivator for humanitarian and development work and provides an important 'logic for its expression'. ${ }^{36}$

Bangladesh secured its independence from Pakistan less than five decades ago, and there is a strong sense in which it remains a 'state in the making', in that both its system and its legitimacy remain under construction. ${ }^{37}$ The struggle to balance multiple and potentially contradictory strands of secular and religious identities continues, and remains as unfinished business. Definitions of national identity based on a majoritarian Muslim national identity have come to dominate over earlier versions of a multicultural Bengali identify that offered equal rights to religious and cultural minorities. Tensions continue, although the urge to understand national identities only through such binaries are also increasingly questioned. ${ }^{38}$ While secular Bangladeshi identities may be in retreat, the country nevertheless remains relatively free of religious extremism and alarmist predictions made during the 2000s that it might become 'the next Afghanistan' did not come to pass. ${ }^{39}$

Public representations of citizen responses in the early weeks of the Rohingya crisis were striking in the ways they seemed to reference and chime with aspects of Bangladesh's own history (Figure 1). The Bangladesh media's coverage of the Rohingya refugees fleeing genocidal violence to arrive at the Bangladesh border revived powerful memories of earlier humanitarian action during the country's own traumatic birth, when ten million Bengali refugees poured into India following the violent repression by the Pakistan army and its collaborators. The abuse of Rohingya rights, the violence perpetrated by vigilante groups orchestrated by a repressive militarised Burmese state, and the systematic use of rape as a weapon of war, were all tropes that served to reawaken memories of this earlier period when Bengalis were themselves subject to severe state sponsored military violence.

Conditions faced by the Rohingya were perceived in media accounts, and reinforced by people's personal stories, to be analogous to those endured by Bangladeshis during the 1971 crisis. A Bangladeshi aid worker told me that in 1971 when (soon to become) Bangladeshis were fleeing the abuses of the Pakistan army in the Chittagong area, some had been protected by Rohingya people across the border in Burma, suggesting an element of reciprocity in the popular Bangladeshi response to the events of 2017. She also drew attention to ideas of selflessness within this contemporary humanitarian discourse to the Rohingya: 'they are poor as we were, and as a citizen I'm proud to do this even if we have to sacrifice some of our standard of living'. I also encountered a more patronising view from some Bangladeshis that today's Rohingya were poor, uneducated people, with large families, and with low levels of inoculation, making them easy to identify with since they were reminiscent of a Bangladeshi population from an earlier age, before it had become developmentally transformed. In this perspective Rohingya were therefore people deserving of both solidarity and 
charity, and were of a condition that rendered them ready for a 'developmental' or humanitarian response.

\section{Figure 1: Visual continuities}

Cox's Bazar, 2017

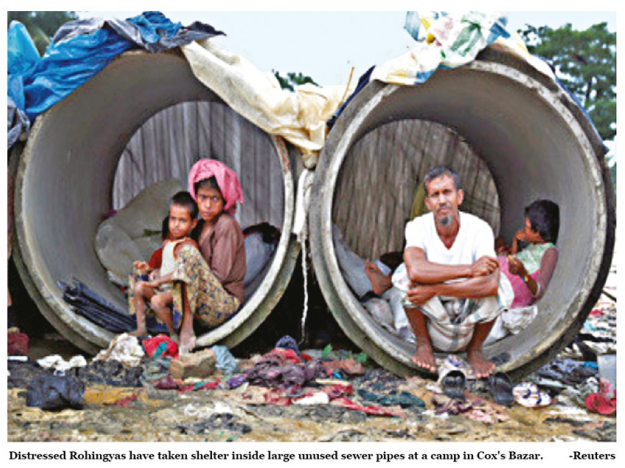

Salt Lake Camp, Calcutta, 1971

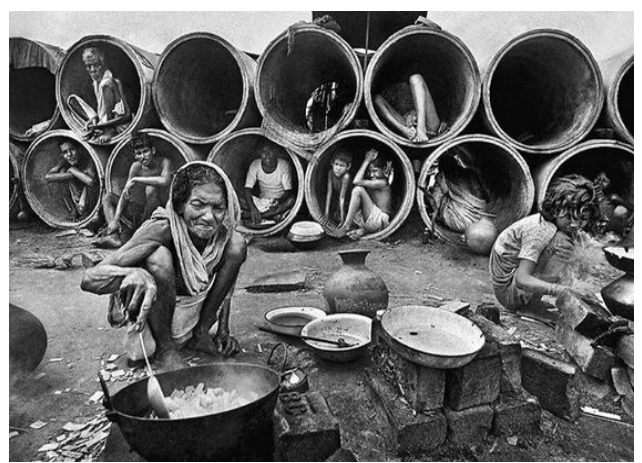

Source: Francis (2017)

An NGO worker and activist who had helped coordinate the international NGO refugee response effort in West Bengal during 1971, drew attention to parallels of representation between the two periods. There are striking similarities in the way photographs of refugees in the local media struck a chord with citizens and the juxtaposed image were being widely circulated in the Bangladesh press during the crisis. ${ }^{40}$ This historical framing resonates with James Thompson's conceptualization of the performance dimension in humanitarian action in the sense that we can see that those who were once 'victims' are now portrayed as (at least having the potential to take on the role of) 'heroes ${ }^{, 41}$. Here also we can see how the working of humanitarian affect and of the power of reciprocity each serve to reinforce the authority of humanitarian action. It also reinforces the need to historicize understandings of local forms of helping and humanitarianism, and with the increasingly recognised need to engage with the power of representation in development more widely. ${ }^{42}$

Returning to the idea of a changing NGO and civil society and sector, the crisis offers insights into the ways that Bangladesh may now be moving towards a 'post-NGO' civil society landscape. The main organisations that contributed to its reputation as leading the way in NGO-led 'alternative' development approaches during the 1980s and 1990s have either faded away, or morphed into other forms of hybrid private organisation. ${ }^{43}$ The large scale local development NGOs that are still operating tend to be focused on microcredit, business development and services rather than rights-based or social mobilisation work - and can these days be more accurately characterised as private 'non-profit' or 'third sector' service providers. BRAC, one of the last of the original large national NGOs that once dominated the country's civil society sector, 
now presents itself primarily as a 'social business', rather than as either an 'NGO' or a 'civil society organisation'.

BRAC has itself been changed by the Rohingya crisis. Its roots were in relief and emergency work during the country's early years, but during the 1980s the organisation had largely moved away from the emphasis on short term relief and reconstruction to concentrate on development work in support of long term change. For founder Sir Fazle H. Abed the opportunity to become involved in the Rohingya relief effort during the 2017 crisis was not only a humanitarian priority but was also a chance for organisational renewal by returning to its original mandate. ${ }^{44}$ In this way, the impulse of everyday humanitarianism does not necessarily bring a break with the past, but returns and feeds cyclically upon it. In BRAC's case this reconnection with its earlier purpose has given it a sense of organisational rejuvenation as it has thrown itself into the Rohingya relief effort, mindful of its own origins in the humanitarian crises that followed the country's devastating November 1970 cyclone and the aftermath of its bloody 1971 Liberation War.

Religious narratives animate local and international helping, but they may also play into historical anxieties about the future and the past. For example, certain 'faithbased' NGOs were as we have seen accused of serving unwelcome political interests during the early stage of the crisis period. This reinforces the idea that humanitarian action rarely serves to create pure moral or non-political spaces, and highlights its entanglement with politics. In October 2017, it was reported that the government's NGO Affairs Bureau, which screens foreign organizations and controls the flow of international funds to local NGOs, had refused permission for three Islamic NGOs Muslim Aid, Islamic Relief, and the Allama Fazlullah Foundation - to work in Cox's Bazar with the refugees. The authorities investigated rumours that these organisations had been distributing JI materials and propaganda. The press reported that the government had explained that barring the organizations was 'a preventative measure against potential radicalization in the camps'. ${ }^{45}$ As Didier Fassin (2012, p.224) has pointed out in the context of Western humanitarian efforts, here too in Bangladesh 'rather than becoming separate, humanitarianism and politics are tending to merge'.

An uneasy accommodation exists in contemporary civil society between the AL government and various religious interest groups. As the AL government has sought to consolidate its dominant position in recent elections, it has worked hard to maintain support not only among its traditional secular support base but also to build new political coalitions, including with religious interests. For example, the largely middle class 2013 Shahbag street protests in Dhaka were a response to concerns that the AL government's International Crimes Tribunal that had been set up in 2009 to retrospectively secure justice in relation to war crimes committed during 1971 by the Pakistan army and its collaborators was wavering in its administration of justice "long delayed" ${ }^{46}$ In 2013 the had wobbled in its determination to follow through on the execution of those convicted of collaborating with the Pakistan authorities in the massacre of Bengali civilians. ${ }^{47}$ The protests were an assertation of secularism that quickly became portrayed as anti-religious by interests sympathetic to the JI leaders who were implicated in the trials. A backlash followed including a counter protest that was coordinated by the Hefazat-i-islami religious movement based in the country's madrasas. Since that time the government has been careful to appease Hefazat, 
including giving in to demands in 2017 that it remove a newly commissioned statue of a female symbolising justice from outside the country's Supreme Court building. ${ }^{48}$

Local humanitarian responses also need to be positioned within the global political economy of Islamic charity, from acts of small-scale private giving to the larger scale Saudi funding of mosques and madrasas. There have been concerns over cases of under the radar 'low profile' private giving from Middle Eastern sources through government channels, particularly in the minds of secular minded Bangladeshi journalists and civil society activists working in the area. One was keen to explain that he had recently observed a wealthy individual donor from the Middle East covertly visiting the local government office with the offer of a project for skills training that was also connected to funds for madrasa development, and that many such overtures were being received and in some cases accepted.

The performance of piety was a visible feature of the local response. In a roadside area near Baluakhali Camp one local landowner spoke of his generosity in allowing a group of Rohingya families to erect shelters on his land, while at the same time gesturing towards the mosque he was now busy constructing based on his request for donations. Here is perhaps an example of what Margrit Talpalaru has termed 'conspicuous giving' 49 , in the form of highly visible acts, which in this context increasingly take religious shape as acts of piety. Disquiet has been voiced in the media about increased numbers of mosques that have been appearing since the crisis began, and the ways in which interest groups from outside - normally meaning the Gulf states - may use charity as a vehicle to for pursuing particular religious agendas. ${ }^{50}$ This resonates with Talpalaru's ideas around visibility and representation: that certain types of charitable acts are performed in public space in order to attract public recognition.

Charitable activity is sometimes understood as separate from market processes but this does not mean it is somehow unconnected from them. This particular landowner also explained that he was now charging rent from these refugee households as they went about setting up their small roadside businesses. He was now also beginning to profit from the situation and extend his reputation. Humanitarian action and local helping, and the acts of piety with which these may be associated, may be intimately connected with markets, sometimes creating new forms of mini market, or new opportunities within existing market processes. Opportunities arise for local business and entrepreneurial activity, with many relief goods such as solar lights and highenergy biscuits highly visible in Cox's Bazar as they were being resold by refugees to local traders in street side markets. This was reminiscent of the 'fluid' technologies that Scott-Smith (2018) observes working with, rather than against, the market in contemporary humanitarianism. ${ }^{51}$

The performance of charity is not the exclusive preserve of donors, NGOs, civil society and organised citizens, but is also part of the work undertaken by government in its efforts to represent, build and sustain its legitimacy. The Bangladesh state can be seen not only in instrumental terms as coordinating the refugee response effort, but also as engaging in another type of performance: that of not only ensuring, but also of demonstrating, that it has everything under control among the camps and the refugee population. This performance is part of the ruling party's enactment of its governance role, where it makes considerable effort not only to manage the crisis but also to 
control representations of its response to the crisis, in order to build political capital locally, nationally, and internationally. The most obvious evidence of this are the banners and posters that dot the roadsides around the country. Many observers in the international community have rightly given the government credit for the ways it is handling the crisis, but this recognition sits uneasily with the fact that the AL's own human rights record is under heavy domestic and international scrutiny. ${ }^{52}$

Figure 2: The visual politics of humanitarianism
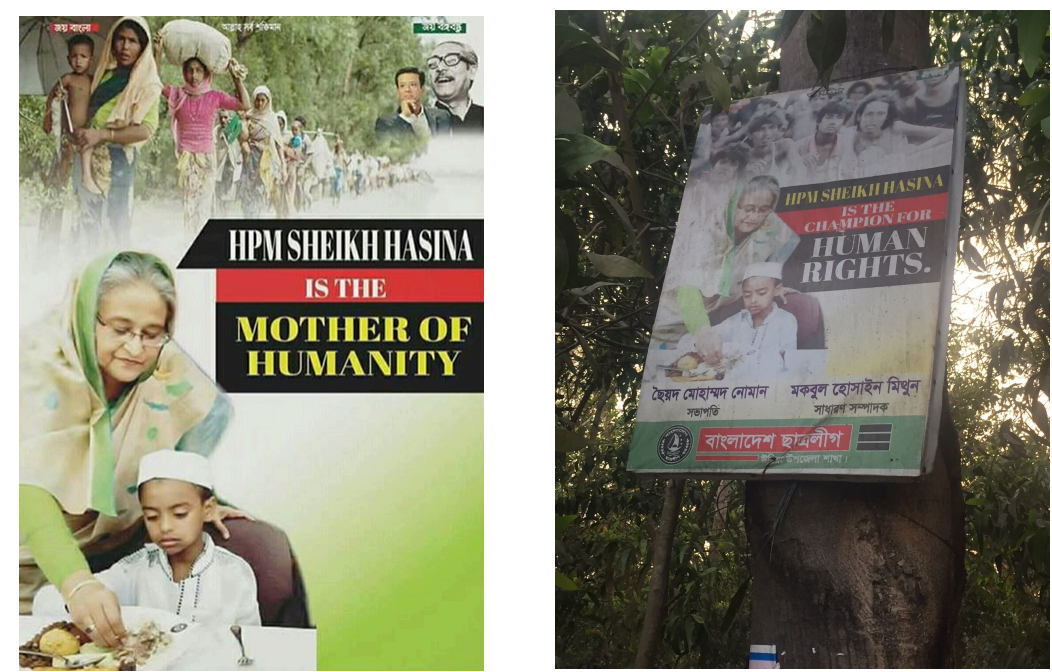

Photo: author

Little of this uncertainty has found its way into the story the government is attempting to tell. Large banners across the roads in Cox's Bazar proclaim that 'Hasina is the mother of humanity' and the 'champion for human rights' (Figure 2), but there is disquiet among local people in Cox's Bazar about the effects on the local economy, and increased indifference at the national level about the Rohingya. One concern is the numbers of unoccupied and potentially disaffected young people in the camps, whose direct experience of religious persecution may make them vulnerable to Islamist political groups who may be operating under the cover of humanitarian work. Another is that in the local economy of Cox's Bazar the prices of essential goods have risen, while the cost of labour has fallen dramatically. A day of labouring on a fishing boat that once brought Tk600 for a day's work can now be offered to a Rohingya worker for Tk200. ${ }^{53}$ Many Bangladeshis now worry that there is every chance that the country will simply be left to permanently absorb another million people. Meanwhile the government has reportedly signed up to a potentially dangerous plan to relocate some of the refugees to silt island of Bhasan Char in the Meghna river estuary, despite protestations from human rights groups. ${ }^{54}$ The diverse impulses of small scale humanitarianism that were observed during the early stages of the crisis have now dissipated, overtaken on the one hand by the formal mainstream international humanitarian machinery, and on the other co-opted by the state's own continuing 
quest for legitimacy and its need to project a stable representation of its governance role.

\section{Conclusion}

The crisis that engulfed a small fishing town in the south east of Bangladesh from late August 2017 generated a varied and complex set of local, national and international humanitarian responses. Following Hilhorst and Jansen, we have analysed humanitarian space as an 'arena' in which a range of actors have shaped humanitarian action through different sets of motivations and everyday realities. ${ }^{55}$ In Cox's Bazar almost immediately ordinary citizens were moved to offer individualised forms of person to person helping, and both informal and formal local organisations soon began improvising relief efforts. NGOs, national and international, some of whom were already working in the area, scaled up their work, attracting media coverage and new resources from the international aid system. Once this space was established, the government with the army took on an overall coordination role. We have argued further that the analytical lens of performance is useful to frame these forms of helping in relation to themes of history, identity and visibility. If we return to Thompson's framework, ${ }^{56}$ we can identify from the case certain key characteristics of humanitarian performance in the form of events (the sudden large scale movement of 700,000 refugees across the border), constructions of heroism (Hasina as the 'mother of humanity'), and narratives of suffering (portrayals of historical continuities between 1971 and the present).

Our focus on citizen helping during the early stages of the crisis also provides insights into two sets of interrelated changes within Bangladesh's civil society. One was an observed gap between the efforts of ordinary citizens who wanted to provide immediate help through a 'do it yourself' approach, and the responses of the public authorities, the formal NGOs, and the international aid system. In part this followed from a time lag between informal individualised responses and formal organisational ones, but it also reflected the growing preference among citizens - in common with that observed elsewhere in the world - for more direct forms of helping alongside, or in place of, formal initiatives and organisations. Local responses to the Rohingya refugees illustrate how more flexible forms of small-scale civic action - as opposed to more formal, externally funded types delivered through professionalised organizations such as NGOs - are becoming increasingly visible within humanitarian and developmental action. The other was that these forms of citizen helping may also reflect growing tendencies among Bangladesh's growing middle classes for more religiously-informed modes of helping within a civil society that is de-secularising. A heightened level of religiosity is part of a wider trend in Bangladeshi society in which the tradition of 'secular rationality or religious neutrality' has shifted in recent years to one in which 'religiously informed voices are now part of the plurality of voices'.

Performances of humanitarian action therefore need to be understood against a changing and sometimes contradictory set of wider political and historical factors that impinge upon the 'social script' that informs charity and helping in Bangladesh society. ${ }^{58}$ These include the efforts of the Bangladesh government to build and balance alliances with both religious and secular interest groups, and more widely, the rise in transnational religious giving. Despite these trends, the forms of small-scale citizen action discussed here are not entirely new. They echo earlier patterns, 
including those that occurred five decades earlier during the country's 1971 War of Liberation. In this sense such activities do not offer a decisive break with the past but can also be understood as cyclical, connected perhaps to 'afterlives of development' ${ }^{59}$ that continue to echo within 'the spirit of previous development regimes'. One cannot fully understand Bangladesh's response to the Rohingya crisis without historical reference to the country's own experience as a nation born in the aftermath of civil and ethnic conflict, following horrific violence perpetrated by a hostile military leading to the creation of a large scale refugee crisis.

Structural processes have influenced forms of local helping, such as the changing ideologies and aspirations of the country's rapidly expanding new middle classes, the shifting international geopolitics of religious charity, and the Bangladesh state's own ongoing efforts to consolidate power within an increasingly authoritarian democracy. ${ }^{60}$ In those initial seconds on the tarmac at Cox's Bazar airport in between receiving my spontaneous invitation to briefly become part of one such performance, and then deciding instead to go on my way, for a short moment it was as if I was present at one of the interfaces of these changing forces and felt its weight. 


\section{Notes}

${ }^{1}$ Although this coverage dwarfed the scale of earlier reporting this was not the first time the Rohingya refugees had made the international news, such as in 2012. See L Brooten \& Y Verbruggen, "Producing the news", 2017.

${ }^{2}$ I am very grateful to Dr Abul Hossain of Green University, Dhaka, with whom I travelled to visit to Cox's Bazar, for our many stimulating conversations; and to Julian Francis, who kindly discussed with me his experiences responding to the plight of Bengali refugees in 1971, his impressions from earlier visits to Cox's Bazar, and on whose account I have drawn upon here. Finally, the paper has benefited greatly from comments from Anke Schwittay and participants at the Citizen Aid and Grassroots Humanitarianism workshop, April 19-20, 2018, University of Sussex, and from comments from two reviewers.

${ }^{3}$ P Redfield and E Bornstein, "An Introduction to the Anthropology of Humanitarianism”, 2010, p.17.

${ }^{4}$ E Bornstein, Disquieting Gifts, 2012, p.174.

${ }^{5}$ L A Richey \& L Chouliaraki, p.314, "Everyday humanitarianism”, 2017; E Bornstein, Disquieting Gifts, 2012.

${ }^{6} \mathrm{~N}$ Thomas et. al., Theme Paper 1: Everyday Humanitarianism. Stockholm: SRC, 2018. See also the work of academics working with the Southern Responses to Displacement initiative (https://southernresponses.org), which highlights community level action taking place.

${ }^{7}$ D Hilhorst and B. Jansen, "Humanitarian space as arena", 2012.

${ }^{8}$ R Schechner, Performance Studies, 2006.

${ }^{9} \mathrm{~J}$ Thompson, Humanitarian Performance: From Disaster Tragedies to Spectacles of War, Calcutta: Seagull Books, 2014.

${ }^{10}$ V Palmer, “Analysing cultural proximity”, 2011.

11 A A Ullah, "Rohingya refugees to Bangladesh", 2011.

${ }^{12}$ I Holliday, “Addressing Myanmar’s Citizenship Crisis”, 2014.

${ }^{13}$ See for example G van Klinken \& Su Mon Thazin Aung, "The contentious politics of anti-Muslim scapegoating”, 2017.

${ }^{14}$ L Brooten \& Y Verbruggen, "Producing the news", 2017.

${ }^{15}$ BBC, 'Myanmar Rohingya: What you need to know about the crisis', 24 April, https://www.bbc.co.uk/news/world-asia-41566561 (accessed 14 September 2018).

${ }^{16}$ A UN fact-finding mission in 2018 argued that members of the armed forces should face prosecution under international law for genocide, crimes against humanity, and 
war crimes. See 'Myanmar military leaders must face genocide charges - UN report', UN News, 27 August 2018. https://news.un.org/en/story/2018/08/1017802.

${ }^{17}$ There has been a growing appreciation and understanding of what has been termed 'community-led protection' in humanitarian situations (see for example Carstensen, 'Understanding and supporting community-led protection', Forced Migration Review, 53, October, pp. 4-7, 2016).

${ }^{18}$ The Independent newspaper 'Bangladesh vows to support one million Rohingya Muslims fleeing Burma: "If needed, we'll eat a full meal once a day and share the rest with them"', October 7, 2017 (accessed December 16, 2018).

${ }^{19}$ A report by the Australian Strategic Policy Institute based on satellite mapping of Rakhine State found continuing destruction of Rohingya villages and "no evidence of widespread preparation for Rohingya refugees to return to safe and dignified conditions' ('Mapping Conditions in Rakhine State', 24 July, 2019, https://pageflow.aspi.org.au/rakhine-state/\#211793).

${ }^{20}$ The country has struggled to escape its labeling during the 1970 s by a United States official as an international 'basket case'. See Lewis, Bangladesh, 2011.

${ }^{21} \mathrm{~K}$ Arnold, 'A farmer, a techie: The Bangladeshis helping Rohingya', Al Jazeera September 14, 2017 https://www.aljazeera.com/indepth/features/2017/09/farmertechie-bangladeshis-helping-rohingya-170914084039681.html (accessed December 16, 2018).

${ }^{22}$ L A Richey \& L Chouliaraki, "Everyday humanitarianism: ethics, affects and practices".

${ }^{23}$ M Roy M, J Hanlon \& D Hulme, Bangladesh confronts climate change: keeping our heads above water, London: Anthem Press, 2016.

${ }^{24}$ Volunteering within the formal INGO sector is another way that everyday humanitarianism has been taking place, but this phenomenon is not the main focus of this article and deserves separate treatment.

${ }^{25}$ BRAC originally stood for 'Bangladesh Rural Advancement Committee', but today it stands as an organisational name rather than an acronym.

${ }^{26}$ See for example I Smillie, Freedom From Want, Kumarian, 2009.

${ }^{27}$ Some use the idea of everyday humanitarianism to understand the experiences of formal volunteers within the NGO sector (cf Thomas et al. 2018), as well as the contrasting forms of voluntary action analysed here as 'informal' types of local helping that took place during the initial moments of the crisis.

${ }^{28}$ Harvard Divinity School, “As Rohingya flee Myanmar, Bangladesh bans three Muslim aid groups”, October 20, 2017. https://rlp.hds.harvard.edu/news/rohingya- 
flee-myanmar-bangladesh-bans-three-muslim-aid-groups (accessed 13 September 2018).

${ }^{29}$ L Olliff, "From resettled refugees to humanitarian actors", 2018.

${ }^{30} \mathrm{~K}$ Arnold, 'A farmer, a techie: The Bangladeshis helping Rohingya'.

${ }^{31}$ D Lewis, Bangladesh, 2011.

${ }^{32}$ See for example H Z Rahman, "The middle class is transforming”, Dhaka Courier, 30th August, 2017.

${ }^{33}$ See F Tasnim, "Politicized civil society in Bangladesh". Civil society today therefore contains contradictory elements of marketization and politicisation that are both complementary and, perhaps, also potentially contradictory.

${ }^{34}$ G D Wood, 'Clashing values in Bangladesh', 2007.

${ }^{35}$ S Huq, 'Muslim aspirations in Bangladesh', 2014.

${ }^{36}$ E Bornstein, The Spirit of Development: Protestant NGOs, Morality, and Economics in Zimbabwe. Stanford, CA: Stanford University Press, 2005, p.54.

${ }^{37}$ D Lewis, Bangladesh, 2011.

${ }^{38}$ A Riaz, Lived Islam and Islamism in Bangladesh, Dhaka: Prothoma Prokashan, 2018 .

${ }^{39}$ H Karlekar, Bangladesh the next Afghanistan?, 2005.

40 J Francis, 'Refugees in 2017 and 1971 - Reflections'. 2017, bd24.com, https://opinion.bdnews24.com/2017/09/28/reflections-on-refugees-1971-and-2017/ (accessed 13 September, 2018)

${ }^{41} \mathrm{~J}$ Thompson, Humanitarian Performance.

${ }^{42}$ See A Schwittay, New Media and International Development, and D Lewis, D Rodgers \& M Woolcock Popular Representations of Development, 2014.

${ }^{43}$ Lewis, 'Representing the poor', 2017

${ }^{44}$ Personal communication, Sir F.H. Abed, Dhaka, March 15, 2018.

${ }^{45}$ Harvard Divinity School, 'As Rohingya flee Myanmar, Bangladesh bans three Muslim aid groups'.

${ }^{46}$ Chowdhury, Paradoxes of the Popular, p.3.

${ }^{47}$ See N Murshid 'The Shahbag Uprising', 2013. 
48 'Statue of woman removed from Bangladesh's Supreme Court', www.nytimes.com/2017/05/26/world/asia/bangladesh-statue-justice-supreme-courtislam.html.

${ }^{49}$ M Talpalaru, 'Blake Mycoskie, Toms, and life narratives of conspicuous giving', 2014.

${ }^{50}$ Bangladeshi migration to the Gulf states since the 1980s is one factor that is believed to have contributed to changing religious attitudes in the country.

${ }^{51}$ T Scott-Smith, 'Sticky technologies', 2018.

${ }^{52}$ See Human Rights Watch 'Bangladesh: Violent Repression of Opposition', https://www.hrw.org/news/2019/01/17/bangladesh-violent-repression-opposition.

${ }^{53} 1$ US \$ is worth around 85 Bangladesh Taka.

54 'Bangladesh prepares to move Rohingya to island at risk of floods and cyclones', The Guardian, July 19, 2019.

${ }^{55}$ D Hilhorst and B Jansen, 'Humanitarian space as arena', 2010.

${ }^{56} \mathrm{~J}$ Thomson, Humanitarian Performance, 2014.

${ }^{57}$ A Riaz, Lived Islam and Islamism in Bangladesh, p.9.

${ }^{58}$ See S C Moeschen, Acts of Conspicuous Compassion, 2013.

${ }^{59}$ See R Rudnyckyj \& A Schwittay, 'Afterlives of development', p.8.

${ }^{60}$ D Lewis and A Hossain, 'Local political consolidation', 2019.

\section{Bibliography}

Bornstein, E. The Spirit of Development: Protestant NGOs, Morality, and Economics in Zimbabwe. Stanford, CA: Stanford University Press, 2005.

Bornstein, E. Disquieting Gifts: Humanitarianism in New Delhi, Stanford, CA: Stanford, 2012.

Brooten, L. \& Y Verbruggen. "Producing the News: Reporting on Myanmar's Rohingya crisis." Journal of Contemporary Asia 47, no. 3 (2017): 440-460.

Chowdhury, N. S. Paradoxes of the Popular: Crowd Politics in Bangladesh. Stanford CA: Stanford University Press, 2019.

Hilhorst, D. and B. Jansen. "Humanitarian Space as Arena: A Perspective on the 
Everyday Politics of Aid." Development and Change 41, no. 6 (2012): 1117-1139.

Holliday, I. “Addressing Myanmar's Citizenship Crisis.” Journal of Contemporary Asia 44, no. 3 (2014): 404-421.

Huq, S. "Muslim Aspirations in Bangladesh: Looking Back and Redrawing Boundaries." In Being Muslim in South Asia: Diversity and Daily Life, edited by R. Jeffrey and R. Sen, 249-268, Oxford: Oxford University Press, 2014.

Lewis, D. Bangladesh: Politics, Economy and Civil Society. Cambridge: Cambridge University Press, 2011.

Lewis, D. "Representing the Poor in a Clientalistic Democracy: The Rise and Fall of Radical NGOs in Bangladesh." Journal of Development Studies 53, no. 10 (2017): 1545-1567.

Lewis, D. \& A. Hossain "Local Political Consolidation in Bangladesh: Power, Informality and Patronage." Development and Change (2019).

Lewis, D., D. Rodgers \& M. Woolcock (eds.) Popular Representations of Development: Insights From Novels, Films, Television and Social Media, London: Routledge, 2014.

Moeschen, S.C. Acts of Conspicuous Compassion: Performance Culture and American Charity Practices. Ann Arbor, MI: University of Michigan Press, 2013.

Murshid, N. "The Shahbag Uprising - War Crimes and Forgiveness in Bangladesh." Economic and Political Weekly 48, no.10 (2013): 13-15.

Olliff, L. "From Resettled Refugees to Humanitarian Actors: Refugee Diaspora Organizations and Everyday Humanitarianism." New Political Science 40, no. 4 (2018): 658-674.

Palmer, V. “Analysing Cultural Proximity: Islamic Relief Worldwide and Rohingya Refugees in Bangladesh.” Development in Practice 21, no.1 (2011): 96-108.

Redfield, P. and E Bornstein. "An introduction to the anthropology of humanitarianism", in Forces of Compassion: Humanitarianism Between Ethics and Politics, edited by P. Redfield and E Bornstein, pp.3-30, Santa Fe, NM: School For Advanced Research Press, 2010.

Riaz, A. Lived Islam and Islamism in Bangladesh, Dhaka: Prothoma Prokashan, 2018.

Richey, L.A. \& L. Chouliaraki, "Everyday Humanitarianism: Ethics, Affects and Practices.” New Political Science 39, no. 2 (2017): 314-316.

Roy, M., J Hanlon \& D Hulme, Bangladesh Confronts Climate Change: Keeping Our Heads Above Water. London: Anthem Press, 2016. 
Rudnyckyj, R. \& A Schwittay “Afterlives of Development”. Political and Legal Anthropology Review 37, no. 1 (2014): 2014.

Schechner, R. Performance Studies: An Introduction, second edition. London: Routledge, 2006.

Schwittay, A. New Media and International Development: Representation and Affect in Microfinance. London: Routledge, 2015.

Scott-Smith, T. "Sticky Technologies: Plumpynut ${ }^{\circledR}$, Emergency Feeding and the Viscosity of Humanitarian Design”, Social Studies of Science 48, no. 1 (2018): 3-24.

Smillie, I. Freedom from Want: The Remarkable Success Story of BRAC, the Global Grassroots Organization That's Winning the Fight Against Poverty. Boulder, CO:

Kumarian Books, 2009

Talpalaru, M. "Blake Mycoskie, Toms, and Life Narratives of Conspicuous Giving", Biography 37, no. 1 (2014): 168-190.

Tasnim, F. "Politicized Civil Society in Bangladesh: Case Study Analyses."

Cosmopolitan Civil Societies: an Interdisciplinary Journal 9, no. 1 (2017): 98-123.

Thompson, J. Humanitarian Performance: From Disaster Tragedies to Spectacles of War. Calcutta: Seagull Books, 2014

Ullah, A.A. "Rohingya Refugees to Bangladesh: historical exclusions and contemporary marginalization.” Journal of Immigrant \& Refugee Studies 9, no. 2 (2011): 139-161.

Van Klinken, G. \& Su Mon Thazin Aung, "The Contentious Politics of anti-Muslim Scapegoating in Myanmar", Journal of Contemporary Asia 47, no. 3 (2017): 353-375.

Wood, G. "Clashing Values in Bangladesh: NGOs, Secularism and the Ummah". ESRC Research Group on Wellbeing in Developing Countries, WeD Working Paper 31. University of Bath, 2007. 